\title{
The Role of Environmental Activists in Governing Riverscapes: The Case of the Yamuna in Delhi, India
}

Alexander Follmann

\section{(2) OpenEdition}

\section{Journals}

Electronic version

URL: http://journals.openedition.org/samaj/4184

DOI: $10.4000 /$ samaj.4184

ISSN: 1960-6060

Publisher

Association pour la recherche sur l'Asie du Sud (ARAS)

Electronic reference

Alexander Follmann, «The Role of Environmental Activists in Governing Riverscapes: The Case of the Yamuna in Delhi, India », South Asia Multidisciplinary Academic Journal [Online], 14 | 2016, Online since connection on 30 April 2019. URL : http://journals.openedition.org/samaj/4184 ; DOI : 10.4000/ samaj. 4184

This text was automatically generated on 30 April 2019.

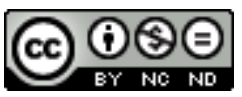

This work is licensed under a Creative Commons Attribution-NonCommercial-NoDerivatives 4.0 International License. 


\title{
The Role of Environmental Activists in Governing Riverscapes: The Case of the Yamuna in Delhi, India
}

\author{
Alexander Follmann
}

\section{Introduction}

India's current urbanization process poses multiple challenges for urban environmental governance. Environmental non-governmental organizations (ENGOs) have emerged as important actors challenging the state to better protect the environment and take actions against urban environmental degradation. A series of case studies indicates that environmental activism seems to be able to make a difference when linking multiple scales and reminding government agencies of their responsibilities in various fields (Hills and Welford 2005, Rajamani 2007, Swerts 2013, Véron 2006). While ENGOs have been acknowledged for their critical role as watchdogs in environmental governance in India (Agarwal 2008, Enqvist et al. 2014, Mawdsley 2004), studies focussing explicitly on the role of ENGOs in urban environmental governance are rare (Dembowski 2001, Enqvist, Tengö and Bodin 2014, Véron 2006) or have predominantly focused on service provisions (water supply, waste management, etc.) through multi-stakeholder arrangements (Baud and Dhanalakshmi 2007, Zérah 2009). By analysing the role of ENGOs in governing Delhi's riverscapes, this paper aims to contribute to the discussion on urban environmental governance and the role of middle-class ${ }^{1}$ environmental activism in India.

2 This paper uses the notion of riverscapes ${ }^{2}$ as a single terminology referring to the riverine landscape shaped by the natural forces of the river and human interventions in multiple ways. Riverscapes refer to a physical space of the river and its surrounding banks, the water and the land. Besides their physical materiality riverscapes are loaded with cultural meanings and discursive representations. As a matter of discourse (Hajer 1995), riverscapes, and the way they are governed, are influenced by different narratives and knowledges of a multiplicity of actors. Therefore, the knowledges of, and 
interactions between, different levels of government, political parties, private businesses, special interest groups, international agencies and a variety of NGOs have to be analysed in order to better understand urban environmental change and governance (Castro 2007:107). In this context, governance is understood as the formal and informal negotiation processes between state and non-state actors that take place beyond the arenas of representative democracy.

Bridge and Perreault (2009:481) indicate that the "rapid and sustained growth" in ENGOs is to be viewed as the "most visible symptom" of the expansion of environmental governance over the last decades. The important role of ENGOs in protecting the environment is widely acknowledged (Bryant 2009, Carter 2007, Mol 2000). It is wellknown that ENGOs disseminate and give voice to environmental knowledges; in doing so, they, however, also filter and reformulate these knowledges in certain ways in order to suit their own interests (Escobar 1998, Robbins 2000, Simon, Forsyth and Thomson 1997). At times, ENGOs are known for "wild" (political) actions and confrontational views in order to initiate change (Bryant 2009).

India's capital city of Delhi, and its river Yamuna in particular, offers a showcase of middle-class environmentalism and its consequences in terms of socio-ecological change. Recent studies have outlined how predominantly middle-class visions have led to socioecological change along the river (Baviskar 2011b, Bhan 2009, Follmann 2014, Ghertner 2011b, 2013). Against this background, this paper outlines the diverse ways environmental activists-almost entirely middle-class people-gain their knowledge and negotiate with the multi-layered state. Based on 72 in-depth interviews with environmental activists, politicians, government officials, scientists and farmers from Delhi's riverscapes (conducted between 2010 and 2013), participant observation as well as an analysis of official planning documents, media reports and court proceedings, the paper traces the environmental activists' day-to-day practices, actions, discursive strategies and networks. In doing so, such an approach follows Rademacher and Sivaramakrishnan (2013b:11), who argue for a more detailed analysis of the "specificities of everyday urban environmental knowledge production, transfer, and application." The main research questions are therefore as follows: How do environmental activists lobby for the river? Which networks do activists weave to gather their environmental knowledge? Which strategies and tools do they use? What impact do they have?

\section{Environmental governance in India: spotlight on rivers}

India's environmental governance is generally characterized by a multiplicity of agencies, overlapping jurisdictions as well as fragmented and ill-defined responsibilities. The longlasting debate for the rejuvenation of India's highly-polluted rivers as well as recent debates for large-scale riverfront developments are showcase examples for the malfunction of the state's environmental protection programmes and agencies. Many observers have called attention to violations of environmental laws and regulations; especially with regard to deficiencies and irregularities in environmental clearances issued by the Ministry of Environment and Forests (MoEF) (Lele, Dubash and Dixit 2010, Panigrahi and Amirapu 2012) and the pollution control mechanisms (Karpouzoglou 2011, Narain 2002). Indian state authorities, in particular the MoEF and the Central Pollution Control Board ( $\mathrm{CPCB})$, officially acknowledged that the institutional mechanisms and the 
implementation of the regulations to protect the environment are insufficient (CPCB 2006, 2010, MoEF 2009).

Especially with regard to rivers and urban water bodies environmental protection in India has sizeably failed. Today, India's urban agglomerations source a large share of their drinking water from surface waters like rivers. Completing the hydrological cycle, the cities discharge millions of litres of untreated or partially treated wastewater into urban streams and rivers. Thus, India's rivers suffer from high degrees of pollution and are often degraded to foul-smelling drains creating serious ecosystem and health problems (CPCB 2006, 2010, CSE 2007, 2012). While large-scale riverfront developments across India are promoted as ecological restoration projects, the creation of iconic and aesthetic riverfronts dominates, and river restoration projects remain largely unsuccessful in ecological terms (Baviskar 2011b, Coelho and Raman 2010, 2013, Desai 2012, Follmann 2015, Mathur 2012, Pessina 2012). In short, a holistic approach for the ecological rejuvenation of urban rivers is a pressing challenge for sustainable urban development and urban environmental governance in India. While this is generally not perceived as such by the state actors, environmental activism has emphasized the ecological integrity of rivers and the close river-city relationships.

\section{Environmental activism in India}

7 Environmental activism in postcolonial India is certainly too wide a field to be discussed in a paper like this. Nevertheless, to better understand the role of environmental activism it is necessary to review the debate in more general terms. Environmental degradation and pollution, but especially the inactivity and shortcomings of the state agencies who do not take actions against these, have led to the creation and proliferation of many different forms of environmentalism and organized environmental movements in India (Gadgil and Guha 1994, 1995, Mawdsley 2004, Narain 2002, Williams and Mawdsley 2006a, 2006b). As in other countries of the Global South, ENGOs have emerged in India as important actors since the 1980s (Sen 1999). In 2007, the directory of ENGOs compiled by WWF-India encompassed about 2,300 ENGOs and this number had increased to about 3,500 ENGOs by the end of 2013. They are engaged in environmental research, public education, information dissemination and training in a large number of fields.

While for a long time studies on environmentalism in India focussed on predominantly rural socio-environmental movements and the often so-called "environmentalism of the poor" (Guha and Martinez-Alier 1997, Martinez-Alier 2002), more recent scholarship has engaged explicitly with questions of socio-ecological conflicts and environmental justice in the context of India's fast growing cities. In this context, the role of the so-called "new middle classes" in shaping post-liberalization urban India has been critically accessed (Brosius 2010, Ellis 2012, Fernandes 2004, 2006, Harriss 2007) and a series of studies has highlighted that middle-class aesthetic environmental imaginaries of clean and green cities have gained excessive influence in spatial politics (Arabindoo 2010, Batra and Mehra 2008, Baviskar 2002, 2011a, Baviskar, Sinha and Philip 2006, Dupont 2011, Ghertner 2008, 2011b, Kumar 2012, Mawdsley 2004, 2009, Rademacher and Sivaramakrishnan 2013a, Sharan 2013, Truelove and Mawdsley 2011). These studies have indicated that organized urban environmental activism shows a rather clear middle-class bias in the way the "public interest" in a clean, green and beautiful city is interpreted and that these visions have often worked against the interests and needs of the poor. In this 
context, Baviskar $(2002,2003,2011 a)$ has coined the term "bourgeois environmentalism."3 The following sections outline the seemingly contrasting debates of the environmentalism of the poor and bourgeois environmentalism.

\section{Environmentalism of the poor}

9 Analyses of environmental movements in India have typically emphasized predominantly rural, marginal and subaltern population groups fighting for the protection of (their) rural livelihoods (Agrawal and Sivaramakrishnan 2001, Baviskar 1995, Gadgil and Guha 1992, 1994, McCully 1996). Covering social environmental movements fighting against deforestation or large-scale development projects (e.g. hydro-power dams, mining, etc.), this "environmentalism of the poor" has largely been a rights-based approach. The internationally best-known examples from India are Chipko Andolan (Chipko Movement), which started in the Garhwal Himalayas of Uttarakhand in the early 1970s resisting large-scale deforestation and Narmada Bachao Andolan (Movement to Save the Narmada) opposing the Sardar Sarovar Dam across the Narmada River in Gujarat.

Socio-environmental action groups in India have traditionally used a wide repertoire of protest drawing on Gandhian-style protest culture. Gandhian non-violent resistance, called satyagraha (literally "truth force"), includes among others protest marches and processions (pradhashan, yatra), sit-down strikes (dharna), or even more militant forms of protest like road blocks (rasta rook) as well as hunger strikes (bhook hartal). During the socalled jail bharo andolan (literally: movement to fill the jails) protesters deliberately break the law in order to get arrested (Gadgil and Guha 1994:121). The so-called padayatra (walking tour) focussing on communication and education is used extensively to call for attention and disseminate views (Gadgil and Guha 1994:122-23). Direct protest has always aimed at media coverage and related public pressure. Traditional movements and grassroots organization have also been engaged in community research and many forms of ecological restoration.

\section{Bourgeois environmentalism}

11 Focusing on a wide variety of urban environmental issues recent writings on environmental activism in India quite critically engage with the role and impact of the urban middle-class. Characteristically, bourgeois environmentalism refers to an underlying "double-think" of middle class environmentalism: on the one hand they are the leading voices for cleaning and greening the cities or creating protected parks and sanctuaries to conserve wildlife and biodiversity, on the other their resource-intensive and affluent lifestyles result in environmental destruction (Baviskar 2002, 2003, 2011a). For Delhi, different authors have shown how urban beautification movements and environmental campaigns have resulted in the demolition of slums (Batra and Mehra 2008, Bhan 2009, Dupont 2007, Dupont and Ramanathan 2008) or the banning of (small-scale) polluting industries leading to the loss of employment opportunities (Baviskar, Sinha and Philip 2006, Kumar 2012, Sharan 2002, 2013, Véron 2006). Other studies have emphasized the inherent contradictions and complex interactions between global aspirations and environmental discourses, which become apparent when contrasting slum demolitions and large-scale development projects in environmentally sensitive areas (Baviskar 2011b, Follmann 2015, 2016, Ghertner 2011b, 2013, Sharan 2015). 
12 Further, studies across India highlight the vital role of the courts, since an increasing number of Public Interest Litigations (PILs) filed especially by middle-class activists has let to numerous court orders regarding environmental protection and pollution amendment (Dembowski 2001, Gill 2012, 2014, Rajamani 2007, Razzaque 2004, Sahu 2014). Based on a relaxation of the locus standi, PILs offer the opportunity that a third party can seek justice in the interest of the public. Originally, PILs were intended to be especially helpful for demanding the rights of socially or economically disadvantaged people, who are not able to demand their rights on their own. Paradoxically, in a considerable number of cases, PILs have led to a further undermining of the rights of the poor (Bhan 2009, Bhushan 2004, Dupont and Ramanathan 2008). Williams and Mawdsley (2006b:668) conclude that the "struggles for environmental justice in India have to contend with a highly unequal 'public sphere,' dominated by the educated and well-connected middle classes." Similar, Gandy (2008:121) highlights that "the political strength of the urban middle classes in India appears to be growing as part of a new discourse of 'environmental improvement'." Especially due to the middle classes' "strong representation in the [English] media, politics, scientific establishment, NGOs, bureaucracy, environmental institutions and the legal system" (Mawdsley 2004:81), they are perceived as being able to mobilize the public discourse in such a manner that their environmental ideologies of a clean and green city are equated with the larger public interest (Baviskar 2011a). Chatterjee (2004) categorically evokes this process:

In metropolis after Indian metropolis, organized civic groups have come forward to demand from the administration and the judiciary that laws and regulations for the proper use of land, public spaces and thoroughfares be formulated and strictly adhered to in order to improve the quality of life of citizens. Everywhere the dominant cry seems to be to rid the city of encroachers and polluters and, as it were, to give the city back to its proper citizens (Chatterjee 2004:140).

13 Thus, in many cases the discourse of the "proper citizens" has been deployed by the middle classes through activism that particularly targets the urban poor; or has pitted, as Chatterjee (2004) termed it, the "civil society" against the "political society." While the civil society has managed to organize and articulate their demands, the political society has largely failed to do so or has been heard by neither politics, state authorities nor the civil society in questions of urban environmental change. It appears that the organized movements of the civil society ${ }^{4}$ use different tools and ways to lobby and influence decisions-making than the above described socio-environmental movements.

Most importantly, the Right to Information (RTI) Act of 2005 granted citizens the right to access a range of information from state authorities, which had earlier remained largely outside the reach of civil society organizations (Naib 2013), and the above mentioned judicial activism through PILs. Additionally, the dissemination of new information and communication technology (ICT) has made information more easily accessible (e.g. Google Earth), and accelerated information exchange between different environmental groups (e.g. via mailing lists, social networks, knowledge portals). Finally, today the English-speaking national print and TV media cover (urban) environmental violations and degradation almost on a daily basis. 


\section{Overcoming dichotomies: environmental activism in India}

The seemingly well-ordered dichotomy of environmentalism of the poor and middle-class activism-corresponding with Chatterjee's conceptualization of political versus civil society-gets blurred when acknowledging the involvement of middle-class activists in socio-environmental movements like Chipko Andolan or Narmada Bachao Andolan (Gadgil and Guha 1994, 1995, Mawdsley 2004). For example, Narmada Bachao Andolan, as Gadgil and Guha (1994:113) stated, "has been widely, and often sympathetically, covered in print media, while it also has well-established links with environmental groups overseas." Thus, the outreach of environmental movements has often been dependant on charismatic leading figures-often middle-class based, metropolitan intellectuals, who were able to inspire others, engage with the media and express their visions in such a way that their message reached both the public and the politicians.

The predominantly negative picture drawn of middle-class activism under the label of bourgeois environmentalism is further at odds with the diversity of urban environmental activism and the wide spectrum of approaches and concerns taken up by middle-class dominated ENGOs engaging in urban environmental policy-making. In this context, Mawdsley (2004:90) rightly argued that "we cannot make any sweeping generalizations about the nature of middle-class environmental activism in India" as the motivations for becoming "environmentally-engaged" vary enormously. Most importantly, it needs to be pointed out that while anti-pollution campaigns have resulted in negative implications for the poor (Baviskar 2011a, Baviskar, Sinha and Philip 2006, Kumar 2012, Sharan 2013, Véron 2006), steep cuts in the lives of the urban poor are often rooted in struggles for the control over spaces in which environmental concerns have been clearly instrumentalized to (re)claim spaces from the poor for fly-overs, metro-lines, apartment complexes, shopping malls or other spaces for consumption and recreation. Thus, it is not a "new" environmental awareness and consciousness which resulted in these anti-poor policies and actions, but rather, as Arabindoo (2010:379) termed it, a "vigorous state-led bourgeois imaginary based on an aestheticized model of order and cleanliness." ${ }^{5}$ This state-led bourgeois imaginary is produced by a class-biased "discourse-coalition" (Hajer 1995) of neoliberal governments, political elites, real estate developers, and middle-class organizations jointly promoting India's megacities to become world-class (Batra and Mehra 2008, Dupont 2011, Ghertner 2015). The dichotomous understanding of environmental activism in India suggests that middle-class environmental activists and ENGOs are always part of this discourse-coalition.

17 Although critically engaging with the role of middle-class activism in general, this paper challenges this seemingly clear dichotomy of environmentalism of the poor and bourgeois environmentalism. However, to avoid any misinterpretations, this paper does not intend to absolve the middle class from their responsibility for environmental degradation or even aim to rehabilitate them in respect to the anti-poor consequences of middle class activism, ecological gentrification and the like (Mawdsley 2004:80). The paper rather wants to contribute to an empirically-informed, multi-layered reading of environmentalism in urban India. Therefore, the remainder of the paper aims to shed light onto the different actions and strategies of ENGOs working for the ecological restoration and conservation of Delhi's riverscapes. Since a wide range of non- 
governmental actors is involved in the remaking of Delhi's riverscapes, it is important to highlight that ENGOs are distinguished here from other middle-class civil society groups (e.g. neighbourhood associations, religious trusts) by their explicit and exclusive environmental agenda.

\section{Introducing Delhi's riverscapes}

18 The river Yamuna takes its source in the glaciers of the Himalayas and confluences with the Ganges in the city of Allahabad. In Hindu mythology, the Yamuna is considered to be a holy river and has been worshipped for thousands of years (Haberman 2006). Flowing for $48 \mathrm{~km}$ through Delhi, the floodplain of the river Yamuna is the largest natural feature and a crucial life-supporting ecosystem of the megacity. Strongly influenced by the monsoon, the river's natural flow varies remarkably during the year and seasonal flooding is most common between July and September. Therefore, the river has been restricted by embankments since the mid-1950s. Nevertheless, with about 800 to 3,000 metres the remaining floodplain is relatively wide even in the central parts of the city. The Yamuna is an important water resource for the megacity; about $30 \%$ of the city's drinking water comes from the river. However, due to high levels of water extraction the river suffers from an insufficient flow of water. This, together with the discharge of untreated sewage, leads to an extremely high degree of pollution. Reports by the CPCB $(2006,2010)$ underline the environmental degradation and the failure of large-scale river cleaning schemes since 1993 under the Yamuna Action Plan (YAP) to bring about an improvement of water quality.

In terms of riverfront development, models of European riverfronts dominated the planning ideology for decades. Especially in the 1980s and 1990s, the Delhi Development Authority (DDA), the city's central planning authority, proposed channelization schemes to reclaim land for large-scale development. However, due to financial and technical restrictions as well as environmental concerns, the DDA failed to proceed with its plans for riverfront development. In order to ensure flexibility for developing the riverfront, the DDA wilfully neglected its duty to plan for Delhi's riverscapes; and a legally binding Zoning Development Plan ${ }^{6}$ wasn't adopted until 2010 (Follmann 2015).

During the past decades, environmental activism with regard to the river Yamuna has generally been focused on three major discourses: 1) questions of minimum water flow in the river, 2) pollution amendment and ecological restoration and most recently 3) the preservation of the floodplain and its protection against built-up developments. While these three distinct areas of intervention have often been discussed separately as the governance of rivers is characterized by sectoral approaches (Follmann 2016:64), the preservation of the floodplain in Delhi cannot be discussed without paying attention to the aspects of pollution and flow in the river as well as taking into account environmental changes in the upstream (e.g. the construction of dams) or flood risks in downstream areas. ENGOs have challenged the sectoral fragmentation of the governance of Delhi's riverscapes by addressing environmental issues on various scales and linking sectoral aspects. This article focusses on the interventions for the preservation of the floodplain while incorporating the other aspects in the analysis. 


\section{Sanitizing the riverfront}

21 In the early 2000s, the High Court of Delhi ordered the demolitions of slums along the river Yamuna in response to a series of PILs filed by factory owners and middle-class neighbourhood associations requesting the removal of slums from their neighbourhoods. ${ }^{7}$ Between 2004 and 2006, all slums along the river in the central parts of the city were demolished. Illegal occupation, polluting activities and environmental degradation, due to non-existing sanitation and drainage facilities, were pointed out by the court and previously-tolerated slums (some existing since the early 1970s) were demolished on ecological grounds. Different authors have rightly described the underlying ideology of the slum evictions as bourgeois environmentalism (Batra and Mehra 2008, Baviskar 2011b, Bhan 2009, Ghertner 2011b, Sharan 2015).

Yet, it needs to be pointed out that it was the court that shifted the focus of the cases to the problem of river pollution, while the original petitions had not mentioned the river. Furthermore, the petitioners had not been seeking the protection of the environment as such, but rather claimed that the slums in their neighbourhoods would negatively affect their businesses and living conditions (Batra and Mehra 2008, Bhan 2009, Ghertner 2011b). While several civil society groups had supported the poor in their fight against eviction (Roy 2004), at the time of the evictions, ENGOs were not involved in the campaigns, and were neither in favour nor against the slums. Some of the ENGOs, which are going to play a major role in the remainder of the paper, did not even exist at that time.

In short, these petitions were not filed by environmentalists and were not seeking the protection of the environment, but rather by middle-class interest groups trying to enhance their quality of life and business environment through the sanitization and purification of spaces along class lines. These interests to beautify and gentrify Delhi's riverscapes, however, dovetailed with ecological concerns to clean the river Yamuna. These had been pending for a long time and were instrumentalized by the state-in this case through the courts-to (re)claim these spaces for developing large-scale infrastructure projects (Follmann 2015).

\section{Protecting the river and the floodplain}

While the slums were removed, construction activities by various state agencies (e.g. Delhi Metro, DDA) were not stopped by the courts, but rather in most cases were even given the final approval (Baviskar 2011b, Follmann 2015, Gill 2014, Sharan 2015). These included, along with others, metro lines and depots, new fly-overs and road-widening projects, the Akshardham Temple complex and the athletes' village for the Commonwealth Games (CWGs) 2010. While the slum demolitions, as outlined above, were legitimized by a drive to revive the Yamuna and protect it from encroachment, these large-scale projects were driven forward almost simultaneously to the evictions; and this despite a court-appointed committee to overview the removing of all encroachments within 300 meters from both sides of the river:

No encroachment either in the form of jhuggi jhopri clusters [slums] or in any other manner by any person or organization shall be permitted. Yamuna has to be redeveloped in such a manner that it becomes the habitat for trees, forests and 
center for recreation. We are making it clear that no structure whether it pertains to religious, residential or commercial or any other purpose shall be allowed to exist. $^{8}$

e case of Delhi Metro, large-scale developments had already begun before the slum evictions proceeded. In 1998, Delhi Metro Rail Corporation (DMRC), a joint-venture of the Government of India and the Government of the National Capital Territory of Delhi, started construction of one of two large-scale depots and an office park (Metro IT-Park) by filling up the Yamuna floodplain with the excavation materials from the tunnelling of underground lines as well as toxic fly-ash from nearby power plants. With regard to environmental concerns, the development of the Delhi Metro has been backed by clear exemptions from the existing environmental laws and regulations. Considered to be railway projects, which are by law exempted from environmental clearance, DMRC does not require environmental clearance from the MoEF for its lines, stations and operational areas, but DMRC needs environmental clearance for its property development projects. ${ }^{9}$ Additionally, as the metro structures were to be constructed on the floodplain the DMRC required technical clearance from the Yamuna Standing Committee (YSC). ${ }^{10}$ Yet, accessed materials (minutes of YSC meetings and environmental clearance materials) indicate that the DMRC either did not apply for clearances, or did not provide full information for its projects, or the state agencies gave these clearances without serious enquiry into these elements. Minutes of YSC meetings further point out that DMRC in some cases acted against the requirements set by the YSC.

The second large-scale project on the floodplain (also in close vicinity to the demolished slums) has been the Akshardham Temple (Srivastava 2009). Without any environmental impact assessment, about 27.5 hectares of land were given by different state authorities to a religious trust for the construction of a Hindu-Temple cum theme park in 2000. A new embankment was constructed by the DDA to protect the temple (opened in 2005) reclaiming about 120 hectares of land. Public protest against these developments remained comparably low even as doubts were raised in different forums (Gill 2014). Only in 2004, the Supreme Court received a PIL by the Uttar Pradesh State Employees Confederation (UPSEC) against the construction of the temple complex pointing to the negative effects in terms of recharge of groundwater and increasing risk of flooding due to a narrowing of the river channel. Based on affidavits by the state of Uttar Pradesh and the DDA, the court, however, dismissed the petition in 2005. ${ }^{11}$ As I have argued elsewhere (Follmann 2015), the state agencies have used informality as "a practice of planning" (Roy 2012:698) in order to bypass existing environmental regulations and make exceptions to realize urban mega-projects for the world-class makeover of Delhi. However, what has been the role of the ENGOs in this process?

While ENGOs like the Centre for Science and Environment (CSE) had long been working on the issue of floodplain protection (Agarwal and Narain 1991), direct protest by ENGOs against these developments seems to have been almost completely absent in this period. A by now well-known Delhi-based environmentalist from a local ENGO recalls the situation in Delhi in those days: "The petition [against Akshardham] was dismissed and no one went into review. No one really bothered about it. We also blame ourselves, because we were very much here and kept sleeping like everybody else in Delhi." ${ }^{12}$ While the ENGOs "were sleeping" in the case of Akshardham, a consortium of different local ENGOs and individuals started organized protest in 2007 under the name Yamuna Jiye 
Abhiyaan (YJA, Yamuna Forever Campaign) against the then planned CWGs-Village, which was supposed to be built on the adjacent land already reclaimed by the embankment.

Using RTI applications ${ }^{13}$ and engaging with scientists working on the river as well as carrying out their own field research, YJA developed a better understanding of the river. Sharing the thereby obtained information through their website and e-mail newsletter as well as considerably engaging with the print and TV media, YJA started advocating against the location of the CWGs-Village and Delhi Metro's projects. In this process, YJA aimed to find and establish scientific facts that large-scale development projects in the floodplain were ecologically harmful both to the river and the city. Therefore, the activists closely exchanged knowledge with scientists and academics from universities and policy think tanks (e.g. Centre for Policy Research, National Institute of Ecology) as well as linked to larger ENGO-networks like the South Asia Network on Dams River and People (SANDRP). One of the activists explained the focus of their initiative, highlighting that it had been "very focused on facts and less on emotions, because it is very easy to speak in terms of a holy river ... but it is better to have facts." ${ }^{14}$ In sum, the activists gained their environmental knowledge through informal contacts and networks, their own fieldwork and documentation of land-use changes by taking pictures and comparing Google Earth time series images as well as through the formal procedure of filing RTI applications.

Based on this information, members of YJA presented their concerns (among others, negative effects on groundwater recharge and risk of flooding) to the public agencies involved. They were given an informal audience with the empowered Group of Ministers in charge of the organization of the Commonwealth Games and the agencies concerned, including the DDA, in November 2007. Informed through further RTI applications to the MoEF, the activists, however, realized that the ministry would finally not oppose the construction of the CWGs-Village. Two separate PILs ${ }^{15}$ were then filed in the High Court of Delhi in 2007 by environmentalists, including members of YJA against the CWGs-Village and the Delhi Metro. While the case was first handled in the High Court of Delhi, which set up a committee to oversee the construction sites, the Supreme Court referring to an affidavit by the National Environmental Engineering Research Institute (NEERI), finally cleared the project based on this expert knowledge by stating that "the site in question is neither a 'floodplain' nor a 'riverbed'."'16

While the petitioning and lobbying for the river at first sight correspond with the armchair middle-class environmentalism often criticized, a more detailed analysis shows that middle-class ENGOs used Gandhian-style protest forms to engage with non-middle class groups as well. For example, the activists initiated a "Yamuna Satyagraha" against the envisaged official start of the construction of the CWGs-Village (see Figure 1). 


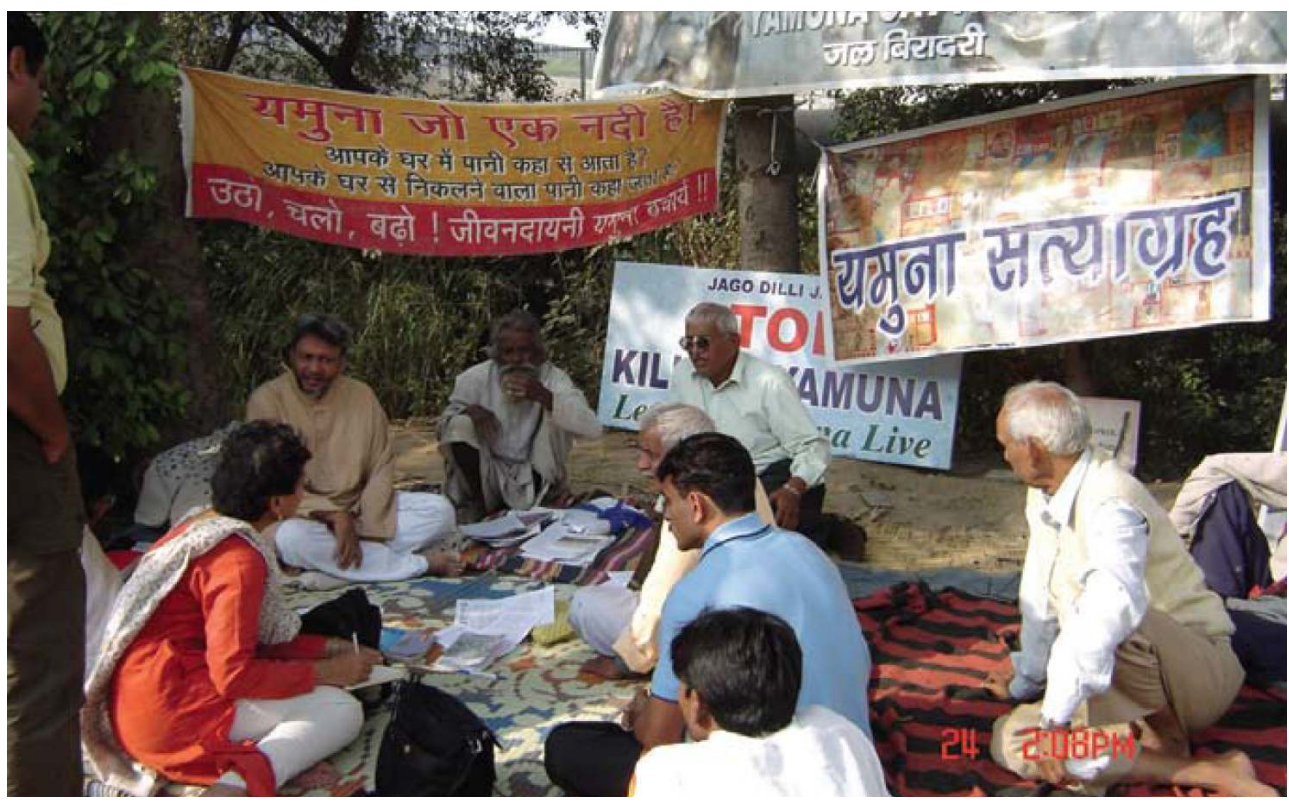

Figure 1: Yamuna Satyagraha (Picture YJA)

31 By planting trees on the supposed construction site, they started a sit-down strike under a large sheesham tree and fasted. Members of other civil-society organizations and wellknown individuals including Vandana Shiva, the lawyer Prashant Bhushan or the journalist Kuldep Nayar joined the protest. The Yamuna Satyagraha was widely covered in the daily newspapers. YJA established multiple connections to non-middle-class groups. Farmers from the floodplain, who were losing their fields, were drawn into the protest. The farmers of Delhi's riverscapes are organized in a farmers' cooperative, the Delhi Peasants Co-operative Multipurpose Society Ltd. which has been fighting court cases against the expulsion from the floodplain since the 1970s. Due to internal organizational problems and heterogeneity of interests among the farmers, the farmers' cooperative was weakened and its earlier political patronage by the Congress Party has also diminished over the last decades (for a detailed analysis of the role of the farmers see Follmann 2016). An ENGO-activist appropriately described the situation of the farmers:

The power of the farmers has to be multiplied by public action or by approaching other institutions like the judiciary. They have no power beyond that. ... They cannot activate the city. They cannot activate the media. ${ }^{17}$

32 Joining forces between the ENGOs and the farmers proved difficult as interviewed ENGOmembers explained, since "the farmers generally don't join Delhi's middle-class and the middle-class generally doesn't join the farmers." 18 Therefore, a key figure of Yamuna Satyagraha was Rajendra Singh, a well-known water conservationist from rural Rajasthan commonly known as "the waterman of India." Members of the ENGO Natural Heritage First (NHF), being part of YJA, requested his support because none of them had ever led a public campaign. They were aware that to start a "real movement" they needed a spokesman, who had "credibility" and "a name working on the ground" and, thus, "being more a rural kind of person," they believed, "the farmers could empathize ... and could understand" him. ${ }^{19}$ Yet, one of the farmers joining the protest pointed out that the cooperation was difficult because of lack of interest from the side of the farmers. ${ }^{20}$ Their limited interest in securing their land in the floodplain might be explained by the fact 
that they were either assigned other plots of land for lease in the floodplain or farming was not their main occupation and source of income. ${ }^{21}$

Besides the Satyagraha, members of YJA also protested at public events (e.g. a groundwater conference inaugurated by the Prime Minister) and disrupted the Delhi Assembly by singing songs and shouting slogans. For these forms of civil disobedience, some of them were taken into custody by the police. One of the activists explained their protest:

Satyagraha doesn't mean just sitting at a place and fasting. ... It is a symbolic part. Satyagraha actually means that if the government doesn't listen to you, you have to violate some law and offer yourself for the prosecution so that the government gets serious and some action develops. ... Fortunately, they understood our intention and they did not file a case. ${ }^{22}$

Thus, similar to the jail bharo andolan the YJA-protesters deliberately violated the law in order to raise attention for their concerns, willing to be taken into custody. However, a larger movement failed to materialize and the Satyagraha terminated a day after the Supreme Court finally cleared the construction. Nevertheless, adopting these typical Gandhian forms of protest and combining them with field research as well as the formal instruments of RTI applications and petitioning, the campaign used a series of channels to raise awareness for the river and oppose the construction of the CWGs-Village. In doing so, the campaign explicitly aimed to link concerns across class differences.

\section{Lasting effects? Developments after the CWGs}

While the CWGs-Village could not be stopped, the protest against it marks a critical point in the overall protection of the river Yamuna in Delhi. The national prestige of the event was sensitive to critique and the media-for a long time uninterested in critically engaging with the river beyond the aspect of pollution-caught on to the campaign and was interested in pursuing it further. After the public outcry against the CWGs-Village and the constitution of the so-called Yamuna River Development Authority (YRDA) by the Prime Minister of India in August 2007, Lieutenant Governor Tejendra Khanna issued a no-development moratorium for the whole river zone in November 2007 (excepting the construction of the CWGs-Village and Delhi Metro). Further, in March 2010 the Ministry of Urban Development approved the Zonal Plan for the river zone prepared by the DDA; no detailed legal plan for the floodplain had existed until this time. Interviews conducted by the author with state officials and politicians indicated that these institutional developments were clear responses to the protest by the ENGOs, which had managed to present their concerns to high-ranking officials during that period.

Based on these institutional developments, the DDA prepared a plan for a biodiversity zone for the whole floodplain to conserve, protect and restore the biodiversity of the river and create new recreational spaces. While developed under the slogan of "biodiversity," the DDA started the initiative by developing a riverfront park (154 hectares), called Golden Jubilee Park. Close to the Old Railway Bridge the area of the park covers parts of an older embankment, which was settled upon by slums until their removal in 2005. With the aim to develop it into a recreational hot spot, the DDA envisioned extended lawns and flower beds as well as an amphitheatre, exhibition areas, a mythological park and a food plaza. The Golden Jubilee Park is a perfect illustration of the middle-class-centred vision of a world-class and consumption-oriented riverfront and 
would presumably be a perfect match as the material outcome of middle-class bourgeois environmental ideology.

However, this ideology has been adapted by the planners and those responsible within the state authorities, not by the ENGOs, which strongly opposed the plans for the biodiversity zone and the development of the park both in the public participation process (which was very limited: request by the DDA to send comments via e-mail) and via the media. They argued that the DDA is "misusing the idea of biodiversity" in order to "create public parks" and pointed out that maintaining these parks is ecologically unsound, as the lawn care will require the use of pesticides and a lot of water. ${ }^{23}$ The farmers also protested against the biodiversity zone concept and were supported by ENGO-members including Rajendra Singh. However, due to the park's green labelling and promotion, it proved to be very difficult for environmentalists and farmers to criticize developments under the biodiversity initiative. One environmentalist explained: "If you take the whole thing of the riverbed as a park ... who will say this is a bad idea? Who will be on your side? You have to create the dialogue. For creating the dialogue you need to have a more intelligent, more sustained intervention." ${ }^{24}$

Yet, spaces for dialogue were not offered by the state; neither to the ENGOs nor the farmers. The ENGOs therefore aimed to create the space for dialogue themselves. In November 2011, artists and environmentalists from Delhi and Hamburg jointly organized the "PROJECT Y: A Yamuna-Elbe Public Art and Outreach Project" on the site of the Golden Jubilee Park. ${ }^{25}$ During public discussion on-site, activists and artists discussed issues related to the river and the history of the site. While local groups like the farmers were involved, the DDA-reluctantly allowing the project to take place on-site-refused to engage in the debate and simply exhibited a 3D-model of the park without any further explanation.

Finally, the whole concept of the biodiversity zone along the river was put on hold by the newly set up National Green Tribunal ${ }^{26}$ (NGT) responding to another PIL by one of the environmentalists (Manoj Misra v. Union of India \& Others, Application No. 6 of 2012). Based on field surveys and photographs as well as information gathered through RTI applications, the PIL challenged the dumping of solid waste in the floodplain. Taking up the concern for the river in a more holistic manner (as was desired by the petitioner), the NGT directed the MoEF to also assess-in addition to the dumping of solid waste-the biodiversity scheme of the DDA. The three-member Expert Committee, set up by the MoEF, declared that the biodiversity scheme "is untenable and should be stopped" (Expert Committee MoEF 2014:5). A day after the NGT had been ordered to review the scheme, the DDA vice-chairman Balvinder Kumar responded via the media ensuring that the DDA would rework the scheme based on the expert committee's recommendation (Singh 2014). As of the writing of this article, the case is still regularly heard by the NGT.

\section{The tools of ENGOs-different strategies and impacts?}

Without doubt, middle-class environmental activism operates most often in different spheres than e.g. protests by the farmers against displacement and the loss of livelihood. Beyond question, the above outlined actions, strategies and impacts of ENGOs working on the river Yamuna are only examples and do not cover the wide variety of their activities. By looking at the local initiative of YJA, a rather clear strategy nevertheless emerges: through the use of RTI applications and their own field surveys, the activists are able to 
gather critical environmental knowledge for lobbying for the ecological restoration and preservation of Delhi's riverscape through the media and for filing PILs in the court. Using the information received through RTI applications, the activists repeatedly write emails to the concerned state authorities or politicians requesting actions to be taken. By sharing these complaints with the media (e-mails in copy) their concerns are most often mirrored in the press. Additionally, the media often request that the addressed officials and politicians comment on the issues raised and, thus, public pressure is produced to act upon the requests made by the ENGOs. Overall, the case study reveals a mediatization of environmental politics which is intended and nurtured by the activists. The mediatization of the protest emerges therefore as an attempt to mobilize the public, the courts and other concerned state actors to act. Analysing the case of the East Kolkata Wetlands, Dembowski (2001:212) suggested that "public interest litigation may be most dynamic when supported by assertive media coverage." Indeed, especially the combination of judicial activism and the mediatization of environmental activism seem to have an effect on urban environmental politics in India.

41 Integrating the English-speaking media in the environmental campaign and the direct links between middle-class activists and the political as well as bureaucracy circles (e.g. by e-mail) correspond with the general debate on the way the civil society, in Chatterjee's terms, including bourgeois environmentalists (cf. Baviskar 2011a:404-05), has managed to organize and articulate their interests through direct links and privileged access. Yet, the example of the Yamuna Satyagraha indicates that it is too simplistic to hold on to both the dichotomous separation of the spheres of the civil versus the political society (Coelho and Venkat 2009, Holston 2009) and the clear-cut distinction between environmentalism of the poor and bourgeois environmentalism as their tools, strategies and spheres of influence clearly overlap. ENGOs have established links to non-middle class communities especially through public campaigns.

The case study further highlights the important role of local ENGOs in generating, disseminating, and mobilizing environmental knowledge about the Yamuna. The ENGOs are key players in the social construction of environmental knowledge, the shaping of public opinion and they strongly influence environmental discourses by challenging government approaches towards the environment. In this context, it is important to note that environmental activists-even across class differences-have internalized the understanding that scientific expertise is crucial for fighting and negotiating with the multi-layered state (Narain 2002, Negi 2011:183). ENGOs are therefore also to some extent dedicated to closing the gap between expert and lay knowledge as their activities are rooted in both spheres (Karpouzoglou and Zimmer 2016).

While not the only tool, the development of RTI is crucial in this context as all interviewees agreed: "Without RTI I would not be sitting here talking to you. ... because I wouldn't know. RTI is amazing. What RTI has done, one cannot imagine. But you have to know how to use it." ${ }^{27}$ In order to enlarge and strengthen their networks, ENGOs exchange information on filing RTIs and PILs. Additionally, environmental lawyers support activists with regard to legal questions. As a result, the Indian judiciary has been challenged over the last decade by the complexity of (urban) environmental aspects and the great number of scientifically backed PILs filed by ENGOs, and the recent setup of the expert-supported NGT is also a response to these developments.

Through RTIs and PILs the state has clearly invited environmental activists to play a more important role. Yet, in contrast to the "invited spaces" of participation (Cornwall 2004, 
Miraftab 2004, 2009) in other spheres of urban governance (e.g. service provisions or the streets), where middle-class activism has even been trained to gentrify the state ${ }^{28}$ (Ghertner 2011a), I argue that the invited spaces in the spheres of environmental protection and ecological restoration are still rather limited; especially when environmental activism is at odds with the state-led bourgeois imaginary of the worldclass city, e.g. opposing large-scale developments (Bhushan 2004:1772). This is certainly connected to a still-low environmental awareness of the public at large. In the case of the Yamuna, a larger movement to critically engage with the protection of the river does not exist. As described in other cases of environmental activism in India (Dembowski 2001, Swerts 2013), environmental activists often remain talking amongst themselves. Yet, as indicated in several interviews, they are aware of these limitations:

[the] problem with the environmental activism is that it only talks to itself. ... activism has to go beyond just confrontation. It also has to have proposals of new ideas and new engagements. ... there are so many nuanced ideas. What about the farmers? What about the people who live there? Are you for them? Are you against them? Do you think farming there is ok? You cannot give a clear answer on that. I think it is much more complex landscape than a black and white. ${ }^{29}$

Additionally, environmental activists face difficulties to resist the co-optation by the government machinery in the course of ecological instrumentalization and the institutionalization of bourgeois environmental thinking. For example, the biodiversity park concept was clearly formulated by the state agencies to suit the concerns of the environmentalists and the recreational needs of the middle-class. Yet, the case also demonstrates that the ENGOs do not simply follow the state-led bourgeois imaginary, but rather especially the smaller ENGOs and their networks and campaigns are still "wild" enough (Bryant 2009) to challenge these hegemonic discourses. Nevertheless, a sustained dialogue between ENGOs and state authorities is absent. One reason, this case study suggests, is the often confrontational activism through the courts. On the one hand, petitioning in the courts facilitates certain changes, but on the other hand it complicates and hinders other forms of more participatory urban environmental governance. It comes out as rather logical that government agencies remain reluctant to share information and deny to open up forums for discussions when ENGOs pressure them to act by filing PILs. Larger ENGOs (e.g. CSE) thus seem to stand off from filing PILs (sometimes even making clear statements against PILs) so as not to lose their influence on the policy level. In sum, environmentalists are challenged to walk a fine line, balancing between protest, petitioning, and policy counselling.

\section{Conclusions}

Based on the analysis of the multiple socio-ecological conflicts around water, pollution and land along the banks of the river, this paper concludes that ENGOs are important actors in collecting, disseminating, (re)interpreting and (re)producing environmental knowledge. The case study corroborates that ENGOs are gaining importance in urban environmental governance. They contribute to political transparency in fulfilling a watchdog role and, thus, foster democratic control. Yet, as many other environmental conflicts in India, Delhi's riverscapes are a highly politicized environment and the case reveals the difficulties of the civil society to engage and negotiate with planners and decision-makers outside the spheres of the media and the courts. 

as the idea of a biodiversity zone, in its principles, entertain visions of reshaping the aesthetic imprint of Delhi on its way to becoming world-class. Delhi's riverscapes emerge here as a critical urban landscape to be retransformed. With regard to the slum demolitions, it was the court and the state agencies (certainly responding to middle-class desires) through which bourgeois environmentalist concerns were institutionalized and ecological aspects instrumentalized to reclaim the riverfront. However, this state-led bourgeois ideology is not shared by the ENGOs and middle-class activists lobbying for the river. Especially, the work of the local ENGOs appears to be a very different kind of environmentalism-clearly distinguishable from this institutionalized bourgeois environmentalism by the state.

different occasions, the middle-class-dominated ENGOs have tried to join hands with the farmers protesting against large-scale developments. Yet, the ENGOs faced difficulties in overcoming the dichotomy between middle-class conservational activism and the interests of the farmers, due to lack of interest by these, different agendas, or a lack of understanding. While the ENGOs aimed to give voice to the local environmental knowledges and needs of the farmers, they have certainly filtered and reformulated their concerns in order to strengthen their own arguments. Progressive ENGOs should more seriously engage in cross-class movements for the protection and ecological restoration of the urban environment in order to overcome the duality of (urban) bourgeois environmentalism and (rural) environmentalism of the poor.

While many challenges remain and the essential awareness to protect and restore the river's sensitive ecosystem still seems to be missing throughout the public at large, the case study stresses that especially local ENGOs-although middle-class dominated-do not exclusively strive for middle-class interests, but rather endeavour for long-term ecological sustainability and social justice for Delhi's riverscapes. In particular, the ENGOs have constantly challenged the sectoral approaches in governing the Yamuna, aiming to link aspects of flow, pollution and land-use change across scales. The ENGOs have forced the judiciary, political actors and policy makers to recognize these interrelationships. However, the governance set-up and the responsibilities of the concerned state agencies remain highly sectoral and the establishment of a holistic governance framework for the Yamuna is still very far from being implemented. Unfortunately, the debate about bourgeois environmentalism almost entirely overshadows these recent forms of urban environmental activism advocating for environmental protection and ecological restoration, as well as socio-ecological justice in the Indian context.

\section{Post-script}

The World Cultural Festival held in the floodplain of the Yamuna in March 2016 by The Art of Living has led to a major new debate regarding the protection of the floodplain in Delhi. The court case against the World Cultural Festival in the National Green Tribunal further highlighted the differences between ENGOs-as I understand them-and other civil society groups interested in the Yamuna. Without going into the details of the case, the fact that the ENGO Yamuna Jiye Abhiyaan, in the person of Manoj Misra, had to bring to court another upper/middle-class civil society organization underpins the argument of this article that middle-class ENGOs act beyond class politics but rather based on an explicit environmental agenda. Besides forcing the state to act against the environmental 
degradation caused by the event, the ENGO-as also in the case of Akshardham and the Commonwealth Games-challenged a mega event which was very much in line with the bourgeois world-class city making agenda. With regard to the argumentation of this article, it is noteworthy that The Art of Living had previously organized activities for the preservation of the river, e.g. cleaning drives under the campaign "Meri Dilli, Meri Yamuna" in 2010. Overall, these very recent developments suggest that the bourgeois environmentalist logic-as visible in the case of The Art of Living's festival in the ecologically sensitive floodplain and especially the organizations handling of criticism both in the media and in the court-only becomes fully apparent if bourgeois environmentalists are directly accused that their actions and lifestyles are responsible for environmental destruction.

\section{BIBLIOGRAPHY}

Agarwal, Anil and Sunita Narain. 1991. “Third Citizens' Report: Floods, Flood Plains and Environmental Myths.” New Delhi: Centre for Science and Environment (CSE).

Agarwal, Anjali. 2008. "Role of NGOs in the Protection of the Environment." Journal of Environmental Research and Development 2: 933-38.

Agrawal, Arun and K. Sivaramakrishnan. 2001. Social Nature: Resources, Representations and Rule in India. Delhi: Oxford University Press.

Anjaria, Jonathan Shapiro. 2009. "Guardians of the Bourgeois City: Citizenship, Public Space, and Middle-Class Activism in Mumbai." City \& Community 8: 391-406.

Arabindoo, Pushpa. 2010. “'City of Sand': Stately Re-Imagination of Marina Beach in Chennai." International Journal of Urban and Regional Research 35: 379-401.

Batra, Lalit and Diya Mehra. 2008. "Slum Demolition and Production of Neoliberal Space: Delhi." Pp. 391-414 in Inside the Transforming Urban Asia: Processes, Policies and Public Actions, edited by D. Mahadevia. New Delhi: Concept Publishing Company.

Baud, Isa and R. Dhanalakshmi. 2007. “Governance in Urban Environmental Management: Comparing Accountability and Performance in Multi-Stakeholder Arrangements in South India." Cities 24: 133-47.

Baviskar, Amita. 1995. In the Belly of the River: Tribal Conflicts over Development in the Narmada Valley. New Delhi: Oxford University Press.

Baviskar, Amita. 2002. "The Politics of the City." Seminar 516. Retrieved March 7, 2016 (http:// www.india-seminar.com/2002/516/516\%20amita\%20baviskar.htm).

Baviskar, Amita. 2003. "Between Violence and Desire: Space, Power and Identity in the Making of Metropolitan Delhi." International Social Science Journal 175: 89-98.

Baviskar, Amita. 2011a. "Cows, Cars and Cycle-Rickshaws: Bourgeois Environmentalism and the Battle for Delhi's Streets." Pp. 391-418 in Elite and Everyman: The Cultural Politics of the Indian Middle Classes, edited by A. Baviskar and R. Ray. New Delhi: Routledge. 
Baviskar, Amita. 2011b. "What the Eye Does not See: The Yamuna in the Imagination of Delhi." Economic and Political Weekly 46: 45-53.

Baviskar, Amita, Subir Sinha and Kavita Philip. 2006. "Rethinking Indian Environmentalism: Industrial Pollution in Delhi and Fisheries in Kerala." Pp. 189-256 in Forging Environmentalism: Justice, Livelihood and Contested Environments, edited by J. Bauer. New York: ME Sharpe.

Bhan, Gautam. 2009. “'This is no longer the city I once knew.' Evictions, the Urban Poor and the Right to the City in Millennial Delhi." Environment and Urbanization 21: 127-42.

Bhushan, Prashant. 2004. "Supreme Court and PIL: Changing Perspectives under Liberalisation." Economic and Political Weekly 39: 1770-74.

Bon, Bérénice. 2015. “A New Megaproject Model and a New Funding Model. Travelling Concepts and Local Adaptations Around the Delhi Metro." Habitat International 45, Part 3: 223-30.

Bridge, Gavin and Tom Perreault. 2009. “Environmental Governance." Pp. 475-97 in A Companion to Environmental Geography, edited by N. Castree, D. Demeritt, D. Liverman and B. Rhoads. Chichester: Wiley-Blackwell.

Brosius, Christiane. 2010. India's Middle Class: New Forms of Urban Leisure, Consumption and Prosperity . New Delhi: Routledge.

Bryant, Raymond L. 2009. "Born to Be Wild? Non-Governmental Organisations, Politics and the Environment.” Geography Compass 3: 1540-58.

Carter, Neil. 2007. The Politics of the Environment: Ideas, Activism, Policy. Cambridge: Cambridge University Press.

Castro, José Esteban. 2007. "Water Governance in the Twentieth-First Century." Ambiente \& sociedade 10: 97-118.

Chatterjee, Partha. 2004. The Politics of the Governed. New York: Columbia University Press.

Coelho, Karen and Nithya Raman. 2010. "Salvaging and Scapegoating: Slum Evictions on Chennai's Waterways.” Economic and Political Weekly 45: 19-23.

Coelho, Karen and Nithya Raman. 2013. "From the Frying Pan to the Floodplain: Negotiating Land, Water, and Fire in Chennai's Development." Pp. 145-68 in Ecologies of Urbanism in India: Metropolitan Civility and Sustainability, edited by A. M. Rademacher and K. Sivaramakrishnan. Hong Kong: Hong Kong University Press.

Coelho, Karen and T. Venkat. 2009. "The Politics of Civil Society: Neighbourhood Associationism in Chennai." Economic and Political Weekly 44: 358-67.

Cornwall, Andrea. 2004. "Introduction: New Democratic Spaces? The Politics and Dynamics of Institutionalised Participation.” IDS Bulletin 35: 1-10.

CPCB. 2006. “Water Quality Status of Yamuna River (1999-2005).” Central Pollution Control Board.

CPCB. 2010. "Status of Water Quality in India: 2010." Central Pollution Control Board.

CSE. 2007. "Sewage Canal: How to Clean the Yamuna." New Delhi: Centre for Science and Environment.

CSE. 2012. "Excreta Matters (Vol.1).” New Delhi: Centre for Science and Environment.

Dembowski, Hans. 2001. Taking the State to Court: Public Interest Litigation and the Public Sphere in Metropolitan India. Cologne: Asia House. 
Desai, Renu. 2012. "Governing the Urban Poor: Riverfront Development, Slum Resettlement and the Politics of Inclusion in Ahmedabad." Economic and Political Weekly 47: 49-56.

Dupont, Véronique. 2007. "Conflicting Stakes and Governance in the Peripheries of Large Indian Metropolises-An introduction.” Cities 24: 89-94.

Dupont, Véronique. 2011. “The Dream of Delhi as a Global City." International Journal of Urban and Regional Research 35: 533-54.

Dupont, Véronique and Usha Ramanathan. 2008. "The Courts and the Squatter Settlements in Delhi: Or the Intervention of the Judiciary in Urban 'Governance'." Pp. 312-43 in New Forms of Urban Governance in India: Shifts, Models, Networks and Contestations, edited by I.S.A. Baud and J. deWit. New Delhi: Sage.

Ellis, Rowan. 2012. “'A World Class City of Your Own!': Civic Governmentality in Chennai, India.” Antipode 44: 1143-60.

Enqvist, Johan, Maria Tengö and Örjan Bodin. 2014. "Citizen Networks in the Garden City: Protecting Urban Ecosystems in Rapid Urbanization." Landscape and Urban Planning 130: 24-35.

Escobar, Arturo. 1998. "Whose Knowledge, Whose Nature? Biodiversity, Conservation, and the Political Ecology of Social Movements.” Journal of Political Ecology 5: 53-82.

Expert Committee MoEF. 2014. "Restoration and Conservation of River Yamuna (Final Report)." Submitted to the National Green Tribunal with reference to Main Application no. 06 of 2012. New Delhi: Expert Committee, Ministry of Environment and Forests comprising of Prof. C. R. Babu (Delhi University, Delhi), Prof. A. K. Gosain (IIT-Delhi), Prof. Brij Gopal (Jaipur).

Fernandes, Leela. 2004. "The Politics of Forgetting: Class Politics, State Power and the Restructuring of Urban Space in India." Urban Studies 41: 2415-30.

Fernandes, Leela. 2006. India's New Middle Class: Democratic Politics State Power and the Re-structuring of Urban Space in India. Minneapolis: University of Minnesota Press.

Follmann, Alexander. 2014. "Delhi's Changing Riverfront: Bourgeois Environmentalism and the Reclamation of Yamuna's Floodplain for a World-Class City in the Making." Pp. 153-76 in Ville et Fleuve en Asie du Sud: regards croisés, edited by H. Joshi and A. Viguier. Paris: Inalco.

Follmann, Alexander. 2015. "Urban Mega-Projects for a 'World-Class' Riverfront: The Interplay of Informality, Flexibility and Exceptionality along the Yamuna in Delhi, India." Habitat International 45, Part 3: 213-22.

Follmann, Alexander. 2016. Governing Riverscapes: Urban Environmental Change along the River Yamuna in Delhi, India. Stuttgart: Steiner.

Forsyth, Tim. 2007. "Are Environmental Social Movements Socially Exclusive? An Historical Study from Thailand." World Development 35: 2110-30.

Gadgil, Madhav and Ramachandra Guha. 1992. The Fissured Land: An Ecological History of India. New Delhi: Oxford University Press.

Gadgil, Madhav and Ramachandra Guha. 1994. "Ecological Conflicts and Environmental Movement in India." Development and Change 25: 101-36.

Gadgil, Madhav and Ramachandra Guha. 1995. Ecology and Equity: The Use and Abuse of Nature in Contemporary India. London: Routledge.

Gandy, Matthew. 2008. "Landscapes of Disaster: Water, Modernity, and Urban Fragmentation in Mumbai." Environment and Planning A 40: 108-30. 
Ghertner, D. Asher. 2008. “Analysis of New Legal Discourse behind Delhi's Slum Demolitions." Economic and Political Weekly 43: 57-66.

Ghertner, D. Asher. 2011a. "Gentrifying the State, Gentrifying Participation: Elite Governance Programs in Delhi." International Journal of Urban and Regional Research 35: 504-32.

Ghertner, D. Asher. 2011b. “Green Evictions: Environmental Discourse of a 'Slum-Free' Delhi." Pp. 145-65 in Global Political Ecology, edited by R. Peet, P. Robbins and M. Watts. London: Routledge.

Ghertner, D. Asher. 2013. “Nuisance Talk: Middle-Class Discourses of a Slum-Free Delhi.” Pp. 24976 in Ecologies of Urbanism in India: Metropolitan Civility and Sustainability, edited by A. M. Rademacher and K. Sivaramakrishnan. Hong Kong: Hong Kong University Press.

Ghertner, D. Asher. 2015. Rule by Aesthetics: World-Class City Making in Delhi. Oxford: Oxford University Press.

Gill, Gitanjali Nain. 2012. "Human Rights and the Environment in India: Access through Public Interest Litigation.” Environmental Law Review 14: 200-18.

Gill, Gitanjali Nain. 2014. "Environmental Protection and Developmental Interests: A Case Study of the River Yamuna and the Commonwealth Games, Delhi, 2010." International Journal of Law in the Built Environment 6: 69-90.

Guha, Ramachandra and Juan Martinez-Alier. 1997. Varieties of Environmentalism: Essays North and South. London: Earthscan.

Haberman, David L. 2006. River of Love in an Age of Pollution: The Yamuna River of Northern India. Berkeley: University of California Press.

Hajer, Maarten. 1995. The Politics of Environmental Discourse: Ecological Modernization and the Policy Process. Oxford: Clarendon Press.

Harriss, John. 2007. “Antinomies of Empowerment: Observations on Civil Society, Politics and Urban Governance in India.” Economic and Political Weekly 42: 2716-24.

Hills, Jonathan and Richard Welford. 2005. "Coca-Cola and Water in India." Corporate Social Responsibility and Environmental Management 12: 168-77.

Holston, James. 2009. "Insurgent Citizenship in an Era of Global Urban Peripheries.” City \& Society 21: $245-67$.

Karpouzoglou, Timothy. 2011. “'Our power rests with numbers.' Re-Visiting the Divide Between 'Expert' and 'Lay' Knowledge in Contemporary Wastewater Governance: New Delhi, India." STEPS Water Symposium, 22-23rd March, Institute of Development Studies, University of Sussex.

Karpouzoglou, Timothy and Anna Zimmer. 2016. "Ways of Knowing the Wastewaterscape: Urban Political Ecology and the Politics of Wastewater in Delhi, India." Habitat International 54: 150-60.

Kumar, Sunalini. 2012. "Clean Air, Dirty Logic? Environmentral Activism, Citizenship, and the Public Sphere in Delhi." Pp. 135-60 in Urbanizing Citizenship: Contested Spaces in Indian Cities, edited by R. Desai and R. Sanyal. New Delhi: Sage.

Lele, Sharachchandra, Navroz K. Dubash and Shantanu Dixit. 2010. "A Structure for Environment Governance: A Perspective.” Economic and Political Weekly 45: 13-16.

Martinez-Alier, Joan. 2002. The Environmentalism of the Poor: A Study of Ecological Conflicts and Valuation. Cheltenham: Edward Elgar Publishing. 
Mathur, Navdeep. 2012. "On the Sabarmati Riverfront. Urban Planning as Totalitarian Governance in Ahmedabad." Economic and Political Weekly 47: 64-75.

Mawdsley, Emma. 2004. “India's Middle Classes and the Environment." Development and Change 35: 79-103.

Mawdsley, Emma. 2009. “'Environmentality' in the Neoliberal City: Attitudes, Governance and Social Justice." Pp. 253-68 in The New Middle Classes: Globalizing Lifestyles, Consumerism and Environmental Concern, edited by H. Lange and L. Meier. Heidelberg: Springer.

McCully, Patrick. 1996. Silent Rivers: The Ecology and Politics of Large Dams. London: Zed Books.

Miraftab, Faranak. 2004. "Invited and Invented Spaces of Participation: Neoliberal Citizenship and Feminists' Expanded Notion of Politics." Wagadu 1: 1-7.

Miraftab, Faranak. 2009. "Insurgent Planning: Situating Radical Planning in the Global South." Planning Theory 8: pp. 32-50.

MoEF. 2009. "Towards Effective Environmental Governance: Proposal for a National Environmental Protection Authority.” Discussion Paper, 17 September 2009. New Delhi.

Mol, Arthur. 2000. “The Environmental Movement in an Era of Ecological Modernization.' Geoforum 31: 45-56.

Naib, Sudhir. 2013. The Right to Information in India. New Delhi: Oxford University Press.

Narain, Sunita. 2002 “Changing Environmentalism.” Seminar 516. Retrieved on March 7, 2016 ( http://www.india-seminar.com/2002/516/516\%20sunita\%20narain.htm).

Negi, Rohit. 2011. “Neoliberalism, Environmentalism, and Urban Politics in Delhi.” Pp. 179-98 in India's New Economic Policy: A Critical Analysis, edited by W. Ahmed, A. Kundu and R. Peet. New York: Routledge.

Panigrahi, Jitendra K. and Susruta Amirapu. 2012. "An Assessment of EIA System in India." Environmental Impact Assessment Review 35: 23-36.

Pessina, Gloria. 2012. “Trying to be 'Sustainable' and 'Global': Ahmedabad and the Sabarmati River Front Development Project.” Presented at the AESOP 26th Annual Congress. Ankara: Association of European Schools of Planning.

Rademacher, Anne M. and K. Sivaramakrishnan. 2013a. Ecologies of Urbanism in India: Metropolitan Civility and Sustainability. Hong Kong: Hong Kong University Press.

Rademacher, Anne M. and K. Sivaramakrishnan. 2013b. "Introduction: Ecologies of Urbanism in India." Pp. 1-41 in Ecologies of Urbanism in India: Metropolitan Civility and Sustainability, edited by A. M. Rademacher and K. Sivaramakrishnan. Hong Kong: Hong Kong University Press.

Rajamani, Lavanya. 2007. "Public Interest Environmental Litigation in India: Exploring Issues of Access, Participation, Equity, Effectiveness and Sustainability." Journal of Environmental Law 19: 293-321.

Razzaque, Jona. 2004. Public Interest Environmental Litigation in India, Pakistan and Bangladesh. The Hague: Kluwer Law International.

Robbins, Paul. 2000. "The Practical Politics of Knowing: State Environmental Knowledge and Local Political Economy.” Economic Geography 76: 126-44.

Roy, Ananya. 2012. "Urban Informality: The Production of Space and Practice of Planning." Pp. 691-705 in The Oxford Handbook of Urban Planning, edited by R. Weber and R. Crane. Oxford: Oxford University Press. 
Roy, Dunu. 2004. “Pollution, Pushta and Prejudice." Delhi: Hazards Centre.

Sahu, Geetanjoy. 2014. Environmental Jurisprudence and the Supreme Court: Litigation, Interpretation, Implementation. New Delhi: Orient Blackswan.

Sen, Siddhartha. 1999. "Some Aspects of State-NGO Relationships in India in the PostIndependence Era." Development and Change 30: 327-55.

Sharan, Awadhendra. 2002. "Claims on Cleanliness. Environment and Justice in Contemporary Delhi.” Pp. 31-37 in Sarai Reader 02: The Cities of Everyday Life, edited by R. Vasudevan, R. Sundaram, J. Bagchi, M. Narula, G. Lovink and S. Sengupta. New Delhi: Sarai, CSDS.

Sharan, Awadhendra. 2013. "One Air, Two Interventions: Delhi in the Age of Environment." Pp. 71-92 in Ecologies of Urbanism in India: Metropolitan Civility and Sustainability, edited by A. M. Rademacher and K. Sivaramakrishnan. Hong Kong: Hong Kong University Press.

Sharan, Awadhendra (2015) “A River and the Riverfront: Delhi's Yamuna as an In-Between Space." City, Culture and Society.

Simon, Batterbury, Timothy Forsyth and Koy Thomson. 1997. "Environmental Transformations in Developing Countries: Hybrid Research and Democratic Policy.” The Geographical Journal 163: 126-32.

Singh, Darpan. 2014. "Will Junk Yamuna Projects to Save Floodplains: DDA." Hindustan Times, April 27.

Srivastava, Sanjay. 2009. "Urban Spaces, Disney-Divinity and Moral Middle Classes in Delhi." Economic and Political Weekly 44: 338-45.

Swerts, Thomas. 2013. "The Democratic Deficit of Transnational Environmental Activism: A Case Study of E-Waste Governance in India." Global Networks 13: 498-516.

Tawa Lama-Rewal, Stéphanie and Marie-Hélène Zérah. 2011. "Urban Democracy: A South Asian Perspective." South Asia Multidisciplinary Academic Journal 5. Retrieved March 7, 2016 (http:// samaj.revues.org/3188).

Truelove, Yaffa and Emma Mawdsley. 2011. "Discourses of Citizenship and Criminality in Clean, Green Delhi." Pp. 407-25 in A Companion to the Anthropology of India, edited by I. Clark-Deces. Chichester: Wiley-Blackwell.

Véron, René. 2006. "Remaking Urban Environments: The Political Ecology of Air Pollution in Delhi." Environment and Planning A 38: 2093-109.

Williams, Glyn and Emma Mawdsley. 2006a. “India's Evolving Political Ecologies.” Pp. 261-78 in Colonial and Postcolonial Geographies of India, edited by S. Raju, M. S. Kumar and S. Corbridge (eds.). New Delhi: Sage.

Williams, Glyn and Emma Mawdsley. 2006b. "Postcolonial Environmental Justice: Government and Governance in India." Geoforum 37: 660-70.

Zérah, Marie-Hélène. 2009. "Participatory Governance in Urban Management and the Shifting Geometry of Power in Mumbai." Development and Change 40: 853-77.

\section{NOTES}

1. I use the term "middle class" in two different ways in this article. The first, and the predominant use, is to refer to the middle class as a sociological category. By referring to 
"middle-class environmental activists," I characterize individuals who, based on their economic status and lifestyle (see among others Baviskar 2003:97, Fernandes 2004:2418), can be considered as middle-class people-no more, no less. Secondly, by talking about middle-class interests, I refer to what has been discussed as specific concerns of the new middle class with regard to urban aesthetics, leisure, safety, and health (Baviskar 2003, 2011a) and the ways through which the middle class has been able to enforce these interests (see among others Brosius 2010, Ellis 2012, Fernandes 2004, 2006, Harriss 2007).

2. As part of my $\mathrm{PhD}$ research I have developed the notion of the riverscapes into a conceptual framework for analyzing the urban environmental governance of Delhi's riverscapes (Follmann 2016).

3. The debate on bourgeois environmentalism in India shares many similarities with "elite environmentalism" in other emerging and developing countries (see among others Forsyth 2007).

4. These include in addition to ENGOs especially neighbourhood associations; in India so-called residents' welfare organizations (see e.g. Anjaria 2009, Harriss 2007, Tawa Lama-Rewal and Zérah 2011, Zérah 2009).

5. See also Mawdsley's (2009) comments on Arun Agarwal's notion of "environmentality" in the urban context.

6. Delhi is divided into 15 planning zones for which Zonal Developments Plans are prepared. The River Zone is a separate planning zone (Zone 0 ).

7. High Court of Delhi, 03 March 2003, Wazirpur Bartan Nirmata Sangh v. Union of India and Others and Okhla Factory Owners' Association v. Government of NCT of Delhi.

8. High Court of Delhi, 08 December 2005, WP(C) No. 2112/2002 and WP(C) No. 689/2004.

9. DMRC has been equipped with great powers for land acquisition to generate parts of the initial project costs through property development (Bon 2015).

10. The YSC is an inter-state body under the chairmanship of the Central Water Commission, Ministry of Water Resources, to oversee all existing structures and to coordinate flood control works along the Yamuna up to Delhi. Proposals for constructions of flood protection measures (embankments, etc.) and public utilities (bridges, etc.) by the riparian states (which are members of the committee) need to be cleared by the YSC.

11. Supreme Court of India 12 January 2005, U.P. State Employees Confederation \& Anr. Writ Petition No. 353 of 2004.

12. ENGO-member, interview by author, Delhi, April 2010 (as agreed with the interviewees, all interviews are anonymized).

13. The author is thankful to the ENGOs for sharing the information and materials accessed through RTI applications.

14. ENGO-member, interview by author, Delhi, April 2010.

15. The first PIL was filed by Tapas NGO. The second PIL was filed by a group of activists including members of YJA, INTACH (Indian National Trust for Art and Cultural Heritage) and Tarun Bharat Sangh.

16. Supreme Court of India, 30th July 2009: Civil Appeal Nos. 4866-67 of 2009.

17. ENGO-member, interview by author, Delhi, 9 December 2011.

18. ENGO-member, interview by author, Delhi, 8 December 2011.

19. ENGO-member, interview by author, Delhi, 8 December 2011.

20. Farmer from the riverbed, interview by author, Delhi, 9 March 2011.

21. Farmer from the riverbed, interview by author, Delhi, 9 March 2011.

22. ENGO-member, interview by author, Delhi, 8 December 2011.

23. ENGO-member, interview by author, Delhi, 7 November 2011.

24. ENGO-member, interview by author, Delhi, 9 November 2011. 
25. The public art and outreach programme initiated by the Ministry of Culture, Hamburg, and carried out in the framework of 'Germany and India 2011-2012: Infinite Opportunities' was held 10-20 November 2011. The project had earlier started with a symposium on the Yamuna and Elbe rivers organized by Max Müller Bhavan in Delhi.

26. The NGT was established on 18.10 .2010 under the National Green Tribunal Act, 2010.

27. ENGO-member, interview by author, Delhi, 6 December 2011.

28. For example through the bhagidari scheme in Delhi (Ghertner 2011a, Srivastava 2009).

29. ENGO-members, interview by author, Delhi, 9 November 2011.

INDEX

Keywords: bourgeois environmentalism, environmental non-governmental organizations, activism, urban environmental governance, public interest litigation

\section{AUTHOR}

\section{ALEXANDER FOLLMANN}

Institute of Geography, University of Cologne 